\title{
Observations on the Anti-Toxic Property of AU-610 Drug on Nicotinism and Alcoholism
}

\author{
by \\ Toyoyuki TAMURA, Yoshiko WAKAMATSU \\ and Jiro MURAKAMI
}

\section{Introduction}

Our Department of Pharmacology, Nihon University School of Dentistry, has been engaged in the pharmacological investigations of various amino acids, particular attention being paid to their anti-toxic aspect. The present study is part of the comprehensive investigations on this subject and it was made possible by the courtesy of Tanabe Pharmaceutical Company, Ltd., which placed at our disposal their asparaginic product which is a species of amino family.

This asparaginic product commonly referred to as AU-610 in the trade, consists of $6 \%$ magnesium salt of asparaginic acid and $4 \%$ potassium salt and is noted for its efficacy for the asthenia attributable to acute liver complaint, nervous prostration, exhaustion from over physical movement, etc. Although there are already available not a few published results concerning its basic aspect, our present objective was to look into its anti-toxic property on nicotine and alcohol.

\section{Experimental}

\section{A. Materials and Procedures}

As nicotine source, a cigarette 'PEACE' (one of the commonest brands sold in Japan) was immersed in the 20 cc RINGER's physiological salt solution or Tyrode solution and its filtrate was used for test purposes. Commonly available whisky, SUNTORY, was similarly used for a series of tests. In connection with these preparations, two kinds of mice were employed; one weighing around $15 \mathrm{~g}$ for oral application of both samples and the other weighing about $2500 \mathrm{~g}$ for the anti-nicotic action of AU-610 in the smooth muscles.

B. Experimental Results.

(1) Relationship between Nicotine and AU-610 in Mice.

Under this heading, two different AU-610 concentrations were used: $0.01 \mathrm{cc} / \mathrm{g}$, and $0.005 \mathrm{cc} / \mathrm{g}$. Respective dosages were injected into the test mice and after half an hour, nicotine solution was subcutaneously administered by way of their dorsal region. While the first group ( $\mathrm{Au}-610,0.01 \mathrm{cc} / \mathrm{g}$ ) all survived an acute nicotinism induced by nicotine administration, the second group (AU-610, $0.005 \mathrm{cc} / \mathrm{g}$ ) showed the following death rate. Each experimental group contained ten healthy mice of the foregoing specifications.

田村 豊幸, 若松 佳子, 村上二朗：Dept. of Pharmacology, Nihon Univ. School of Dentistry (Chief: Prof. Mikio Sato). 
Table 1. Acute Nicotinism and AU-610 Administration

AU-610

$$
0.01 \mathrm{cc} / \mathrm{g}
$$

(Subcut. inj.)

Survival

AU-610

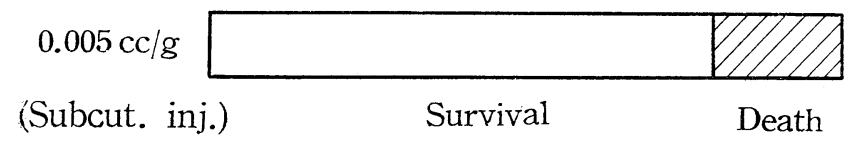

(2) Relationship between Alcohol and AU-610 in Mice.

Under this part of experimentation, the alcohol sample SUNTORY was mixed with the corresponding volume of water for one group of mice and SUNTORY mixed with the corresponding volume of AU-610 was adminstered for the second group for comparative purposes.

Table 2. Acute Alcoholism and AU-610 Administration

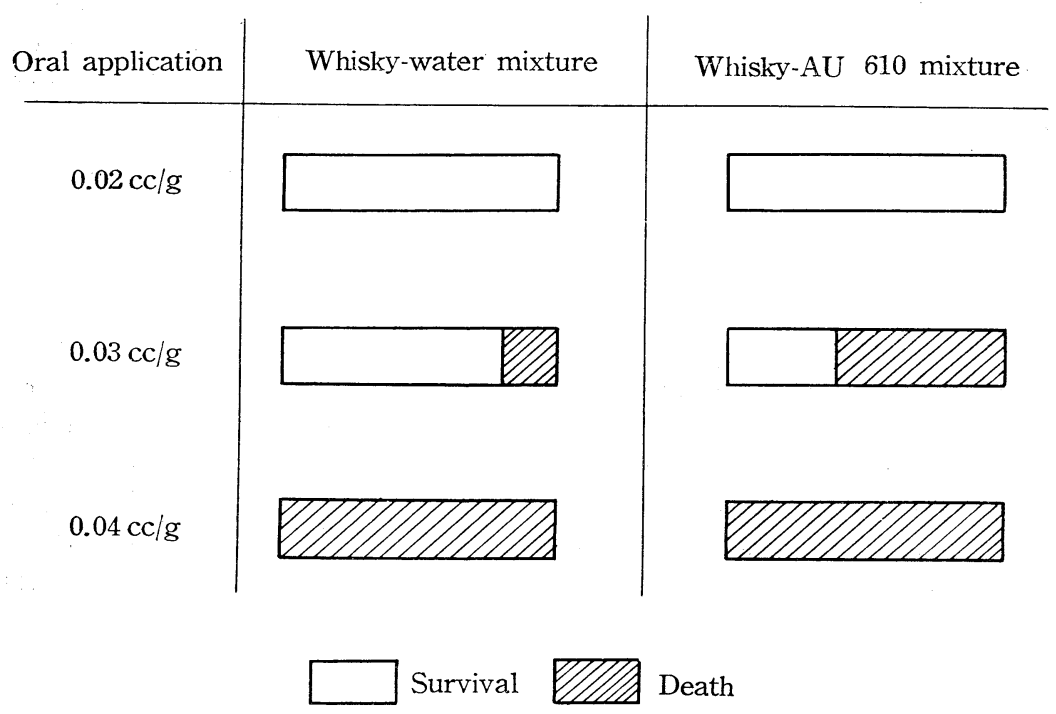

From the findings obtained (Table 2), it may be concluded with the volume of administration the alcohol on SUNTORY proved more potent when mixed with AU610 than the dilution by means of water. It is yet to be determined whether this tendency will give rise to a different direction when the volume of AU-610 adminstration is either increased or decreased.

(3) Relationship between Nicotine and AU-610 in the Jejunums of Mice.

When $0.3 \mathrm{cc}$ nicotine solution was dropped into the Tyrode solution of $30 \mathrm{cc}$, one observed the curve of jejunum contractions each time a drop was added to the Tyrode liquid.

It was only after the confirmation of this occurrence that effect of AU-610 was investigated. When $0.3 \mathrm{cc}$ AU-610 solution was tried on the said Tyrode liquid, one 
Table 3.

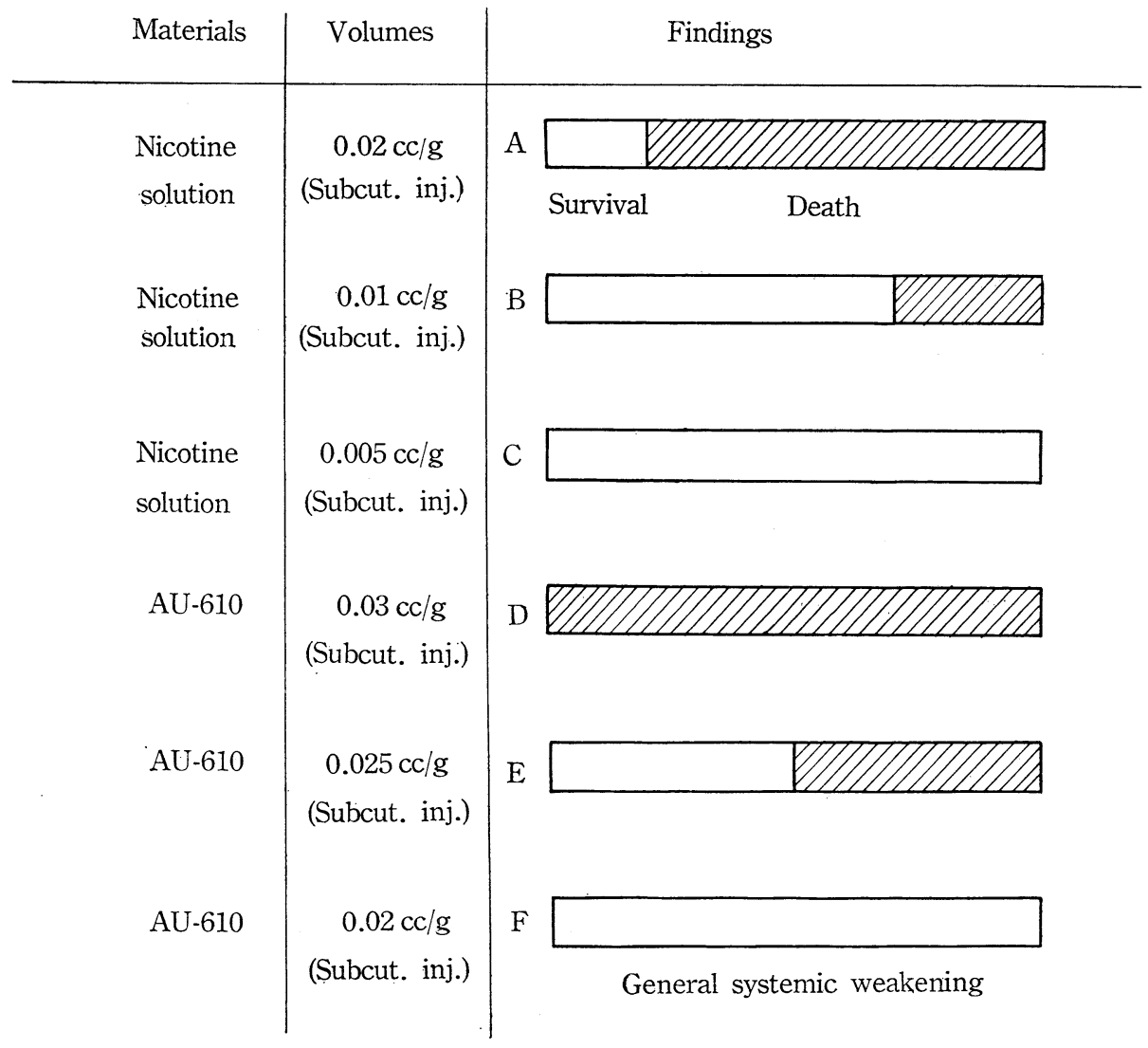

found that the autonomic movement of jejunums came to be checked to a great extent, though not completely. When a few drops of nicotine solution as was used in the previous test were added, a tendency took place which was somewhat inhibited the movement than the medication of AU-610 but no remarkable change was apparent (Fig. A).

Similarly, when AU-610 was increased from $0.03 \mathrm{cc}$ to $0.4 \mathrm{cc}$ the autonomic movement on the part of rabbit jejunums was almost completely checked and the addition of nicotine solution had effects in inhibiting the movement by nearly $60 \%$ (Fig. B). When $0.5 \mathrm{cc}$ AU-610 solution was administered, the autonomic movement was completely checked and the addition of nicotine proved effective in inhibiting the contractive movement (Fig. c).

From these series of three tests, one may conclude that AU-610 medication though depending upon its proper concentration can completely check the contractive movement of mouse jejunums owing to nicotine.

\section{Conclusion}

AU-610 drug, which is an asparaginic acid product composed of Magnesium sodium $6 \%$ and Kalium salt $4 \%$, is found to have a slight anti-toxic effect on nicotine infused 

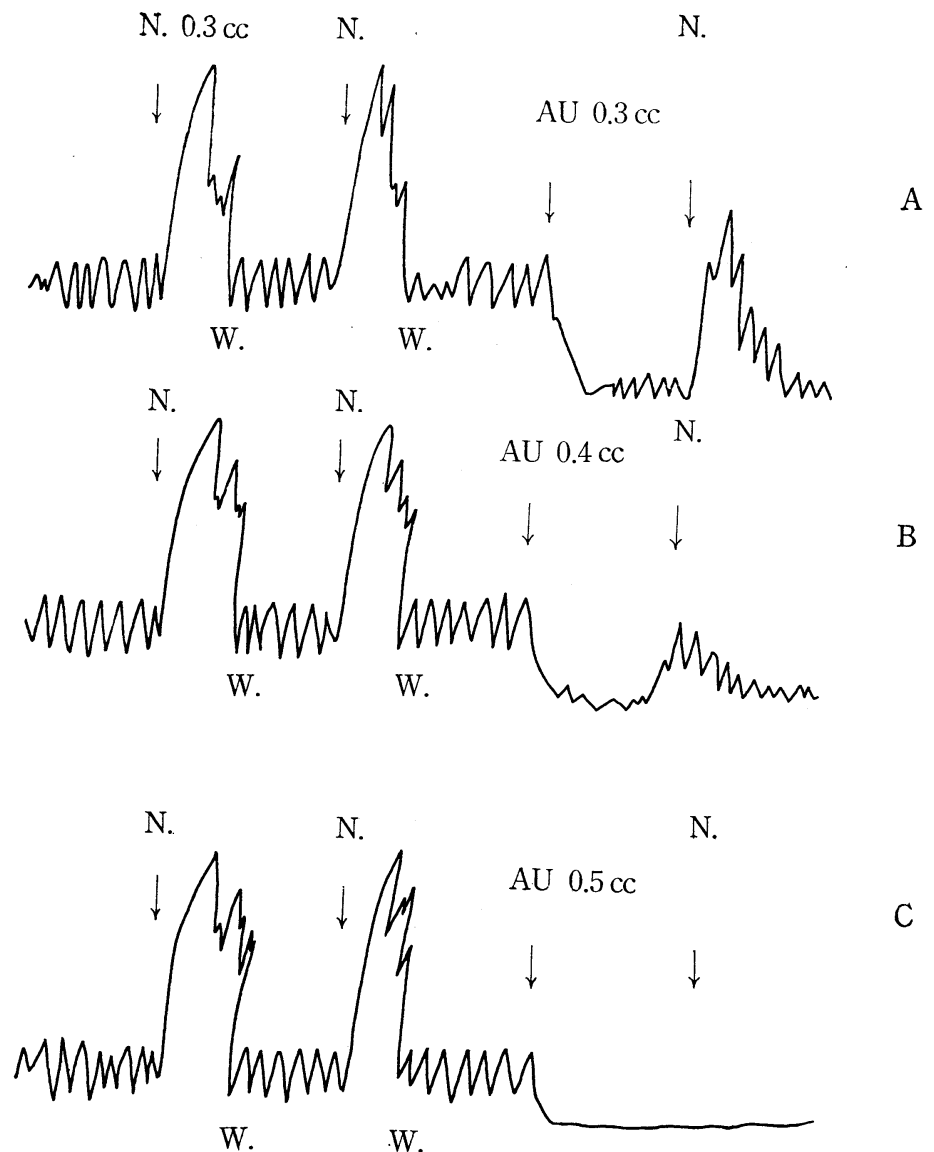

$\mathrm{C}$

Fig. A, B, C.

from the common commercial Japanese cigarette but, on the other hand, it seems to augment the alcoholic effect as attested by a series of tests with a whisky. AU-610 also acts strongly on the contractive movement of mouse jejunums to a remarkable degree.

Based on these findings, it can be stated that with sufficient manipulation with regard to its proper concentration, AU-610 has a vast possibility to be used as a potent antidotic agent.

\section{References}

[1] H. LABORIT et al.: The Position of a Few DL-Asparaginic Acids in the Position of Response Maintenance to Environment, Presse Méd., 66 (57), 1309, 1958

[2] Ditro: Actions of DL-Asparaginic Acid $\mathrm{K}$ and $\mathrm{Mg}$ Salt on the Total Serum $\mathrm{CO}_{2}$ brought about in Dogs through Excessive Carbon in Blood, C. R. Soc. Biol., 152, 1094, 1958

[3] R. Moynier et al.: Influences of Various Pharmacological Substances on the Swimming Tests of Mice, C. R. Soc. Biol., 152, 486, 1958

[4] Ditro: Influence of Ion Composition of Cell Outer Fluid on the Swimming Test of Mice 
and a Comparison among Asparaginic Acid, Asparaginic Natrium and Glucose, C. R. Soc. Biol., 151, 1383, 1951

[5] P. LEguen et al. : A Study on the Change of Blood Ammonia in the Swimming Test of Mice and Actions of DL-asparaginic Acid K and Mg Salt, C. R. Soc. Biol., 152, 1359, 1958

[6] T. TAmaki et al. : On the Pharmacological Actions of Asparaginic Acid $\mathrm{K}$ and $\mathrm{Mg}$ Salt (Jap. text), Yakugaku-Kenkyu, 33, 8, 149, 1961

[7] B. WeBER et al. : Actions of a Certain DL-asparaginic Acid K on Acute Poisoning Ammon Chlorate, C. R. Soc. Biol., 152, 486, 1958

[8] G. ZAwodowsky et al. : Changes in Blood Ammonia through the Injection of Ammon Chlorate into Rabbits, Anesthésie, Analysie Reanimation, 16, 420, 1959

[9] C. BARON et al. : Preliminary Note to an Experimental Study on a Few Asparaginic Acids, Anesthésie, Analyse, Reanimation, 15, 480, 1958

[10] A. KRUSE: Therapy of Fatigue by means of Asparaginic Acid Salts, Northwest Med., 60, 597,1961

[11] B. Weber et al. : E. C. G. Changes in the Cardiac Stenosis experimentally induced in Rabbits, C. R. Soc. Siol., 152, 431, 1958

[12] A. TRzebski : An Increase of Resistence to Anoxia of Irrigated Heart by the Administration of Asparaginic Acid Salts, Presse Méd., 67 (59), 2259, 1959

[13] T. M. TouAng et al. : A Biological Study on the Injection of Asparaginic Acid Salt and Mg Salt in Human Clinic, Anesthésie, Analyse, Reanimation, 16, 415, 1959

[14] P. Leguen et al. : Effects of DL-asparaginic Acid Salt and Mg Salt on Hyperammonia in Blood in Experimental Bleeding Shocks, C. R. Soc. Biol., 152, 942, 1958 